\title{
Letter to Editor: Efficacy of Lofexidine in the Outpatient Management of Tramadol Withdrawal Syndrome
}

\author{
Mohammad Majidi ${ }^{1}$ (D), Solmaz Nekoueifard ${ }^{2 *}$ (iD \\ 1. Department of Forensic Medicine and Clinical Toxicology, School of Medicine, Urmia University of Medical Sciences, Urmia, Iran \\ 2. Urmia Health Center, Urmia University of Medical Sciences, Urmia, Iran.
}

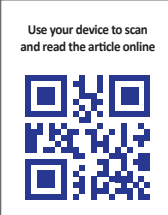

ditation: Majidi M, Nekoueifard S. Efficacy of Lofexidine in the Outpatient Management of Tramadol Withdrawal Syndrome. International Journal of Medical Toxicology and Forensic Medicine. 2020; 10(4):32270. https://doi.org/10.32598/ijmtfm.v10i4.32270

doi https://doi.org/10.32598/ijmtfm.v10i4.32270

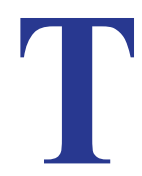

ramadol is recognized as an opioid with non-opiate properties. It has a low affinity for opioid receptors and prevents reabsorption of norepinephrine and serotonin at synapses. It also increases the level of Gamma-Aminobutyric Acid (GABA) in the central nervous system $[1,2]$. Tramadol is an analgesic for patients suffering from moderate to severe pain [1]. In addition, previous studies have shown that tramadol abuse and suicidal attempts have increased in Iran [3, 4]. Tramadol is a highly toxic opioid, causing severe side effects, such as withdrawal syndrome, respiratory distress, rhabdomyolysis, acute renal failure, seizures, and death [5]. In recent years, tramadol withdrawal syndrome and its treatment have become an important issue in the healthcare system [6]. Symptoms of tramadol-induced withdrawal syndrome are restless legs syndrome, insomnia, irritability, diarrhea, insomnia, abdominal spasm, headaches of migraine type, dysfunction of the autonomic system, and myoclonus in extremities $[7,8]$. Also, psychosis with its signs and symptoms, such as paranoia, illusions, and delusions are the atypical discomforts in the tramadol withdrawal syndrome [9]. Alpha-2 adrenergic agonists are valuable for the management of withdrawal syndrome due to opioids by reducing the noradrenergic effects in the brain and all symptoms of withdrawal syndrome, such as anxiety, irritability, and restlessness in opioid-dependent patients [6]. Most of these agonists (clonidine and lofexidine, etc.) are considered to be effective for opioid withdrawal syndrome. Lofexidine is an alpha- 2 adrenergic agonist that is structurally similar to clonidine, and in comparison with clonidine, Lofexidine has low side effects, such as bradycardia and hypotension [10, 11]. Accordingly, lofexidine seems to be effective for tramadol withdrawal syndrome. Therefore, further studies are needed in the future.

\section{Ethical Considerations}

\section{Compliance with ethical guidelines}

All ethical principles are considered in this article.

\section{Funding}

This research did not receive any specific grant from funding agencies in the public, commercial, or not-profit sectors.

\section{Author's contributions}

All authors contributed to preparing this article.

\section{Conflict of interest}

The authors declared no conflict of interest.

* Corresponding Author:

Solmaz, Nekoueifard, MD.

Address: Urmia Health Center, Urmia University of Medical Sciences, Urmia, Iran.

Tel: +98 (41) 33668291

E-mail: solmaznekoie60@gmail.com 


\section{Acknowledgements}

The authors would like to express their gratitude to the three patients who agreed to voluntarily participate in this study. They also wish to thank the management and staff of Taleghani Hospital, Urmia, Iran, for supporting this study and approving its protocol prior to implementation.

\section{References:}

[1] Habibollahi P, Garjani A, Shams Vahdati S, Sadat-Ebrahimi SR, Parnianfard N. Severe complications of tramadol overdose in Iran. Epidemiol Health. 2019; 41:e2019026. [DOI:10.4178/ epih.e2019026] [PMID] [PMCID]

[2] Stacey BR, Dworkin RH, Murphy K, Sharma U, Emir B, Griesing T. Pregabalin in the treatment of refractory neuropathic pain: results of a 15-month open-label trial. Pain Med. 2008; 9(8):1202-8. [DOI:10.1111/j.1526-4637.2008.00423.x] [PMID]

[3] Ripamonti C, Fagnoni E, De Conno F. Withdrawal syndrome after delayed tramadol intake. Am J Psychiatry. 2004; 161(12):2326-7. [DOI:10.1176/appi.ajp.161.12.2326] [PMID]

[4] Tarkkila P, Tuominen M, Lindgren L. Comparison of respiratory effects of tramadol and pethidine. Eur J Anaesthesiol. 1998; 15(1):64-8. [DOI:10.1046/j.1365-2346.1998.0233a.x] [PMID]

[5] Kabel JS, van Puijenbroek EP. Bijwerkingen van tramadol: 12-jaar ervaring in Nederland [Side effects of tramadol: 12 years of experience in the Netherlands]. Ned Tijdschr Geneeskd. 2005; 149(14):754-7. https://www.ntvg.nl/system/ files/publications/2005107540001a.pdf

[6] Flemming H, Hoffman R. A commentary: Do a2-adrenergic agonists decrease the symptoms associated with opioid withdrawal? Ann Emerg Med. 2018; 71(2):268. [DOI:10.1016/j. annemergmed.2017.09.033] [PMID]

[7] Park YM, Park HK, Kim L, Lee HJ, Kang SG. Acute-withdrawal restless legs syndrome following abrupt cessation of short-term tramadol. Psychiatry Investig. 2014; 11(2):204-206. [DOI:10.4306/pi.2014.11.2.204] [PMID] [PMCID]

[8] Barsotti CE, Mycyk MB, Reyes J. Withdrawal syndrome from tramadol hydrochloride. Am J Emerg Med. 2003; 21(1):87-8. [DOI:10.1053/ajem.2003.50039] [PMID]

[9] Sidana A, Domun I, Arora P. Tramadol withdrawal psychosis. Indian J Psychiatry. 2019; 61(6):655-6 [DOI:10.4103/psyy chiatry.IndianJPsychiatry_11_19] [PMID] [PMCID]

[10] Gish EC, Miller JL, Honey BL, Johnson PN. Lofexidine, an \{alpha\} 2-receptor agonist for opioid detoxification. Ann Pharmacother. 2010; 44(2):343-51. [DOI:10.1345/aph.1M347] [PMID]

[11] Nair AS. Lofexidine for treating opioid withdrawal syndrome in palliative care patients. Indian J Palliat Care. 2018; 24(4):546-7. [DOI:10.4103/IJPC.IJPC_103_18] [PMID] [PMCID] 